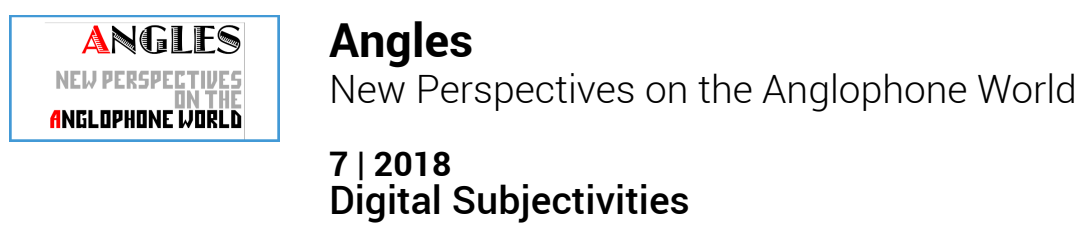

\title{
Langston Hughes's Poetic Vision of the American Dream: A Complex and Creative Encoded Language
}

Christine Dualé

\section{(2) OpenEdition}

Journals

Electronic version

URL: https://journals.openedition.org/angles/920

DOI: 10.4000/angles.920

ISSN: 2274-2042

Publisher

Société des Anglicistes de l'Enseignement Supérieur

Electronic reference

Christine Dualé, "Langston Hughes's Poetic Vision of the American Dream: A Complex and Creative Encoded Language", Angles [Online], 7 | 2018, Online since 01 November 2018, connection on 06 June 2022. URL: http://journals.openedition.org/angles/920 ; DOI: https://doi.org/10.4000/angles.920

This text was automatically generated on 6 June 2022

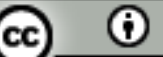

Angles est mise à disposition selon les termes de la Licence Creative Commons Attribution 4.0 International. 


\title{
Langston Hughes's Poetic Vision of the American Dream: A Complex and Creative Encoded Language
}

\author{
Christine Dualé
}

1 In his collection of poems entitled Montage of a Dream Deferred (1951), Langston Hughes observed and gave a particularly original restitution of the historic evolution of African-American culture. ${ }^{1}$ Montage was, indeed, largely shaped by the impact of the transformation of Black music as well as the hopes and dreams of African Americans. The poems, like be-bop and jazz, are marked by conflicting changes, sudden interjections, broken rhythms and are "punctuated by the riffs, runs, breaks and distortions of the music of a community in transition." (Rampersad 387) Hughes's musical poetry was revolutionary both in its form and ideology. He repeated his experiment with Ask Your Mama: 12 Moods for Jazz in 1961, inspired by free-jazz and where Black music constitutes the thematic unity that holds the poems together.

2 Hughes gained his reputation as a "jazz poet" during the jazz era or Harlem Renaissance of the 1920s. ${ }^{2}$ By applying the jazz and blues techniques to his writing, Hughes originally portrayed ordinary Black life; it also allowed him to revive this type of music which he considered the very expression of Black soul. ${ }^{3}$ Though Hughes was not the first one to use Black music in his writing, he was the first and only to make jazz the principle of his writing and to apply the blues technique to translate the same emotion and sensitivity of ordinary Black people. After his musical and experimental phase in the 1920s and 1930s, Hughes turned to other forms of experimentations in his poetry like manifestos or letters. His poetic evolution followed the evolution of history, of Black-American history, but also the evolution of all forms of art, and of music in particular. Montage, which was published in 1951, is the description of the life of the African-American community of Harlem through 87 poems all inspired by be-bop. Hughes experimented free-jazz in his writing and radically changed the way his work was perceived. His resistance to a form of polished art implied an ideology and culture different from his fellow writers and poets. "White self-interest under the guise of 
patronage often detours Black people from self-knowledge and self-awareness. Black voices of the 1920s [like Langston Hughes] demonstrate the complexities that result from that displacement." (Archer-Straw 177) As Petrine Archer-Straw also states in her study of avant-garde Paris and Black culture in the 1920s:

Many black intellects were disquieted by the white vogue for blackness. They recognized how frivolous and temporal it was, and the extent to which their culture was being admired for all the 'primitive' qualities from which they wished to be distanced. A troubled Langston Hughes expressed his concern in The Big Sea, and noted how distortions in black artistic practice were developing because of blacks' interaction with whites. [...] The problem for artists like McKay, Langston Hughes and Paul Robeson was how to cross over into mainstream artistic circles while maintaining their integrity and commitment to the black cause. (Archer-Straw 175)

As a matter of fact, Hughes maintained his commitment to the Black cause all along his career and succeeded in navigating the two worlds of Black and White intelligentsia and in maintaining his cultural posturing at a time when Black positive cultural images were promoted and when his representation of humble Black people was resented.

The theme of the American Dream and the possibilities for the Black man to reach and to accomplish this dream are recurrent in Hughes's poetry. Montage was largely shaped by the impact of the transformation of Black music as well as the hope and dreams of African Americans. The tension between the realities of the Black experience and the unrealized dream provided the dynamic of Hughes's writing. W. Jason Miller (2015) argues Martin Luther King's dream owes to Hughes's poetry and vision as both men articulated the dream of better lives for the oppressed and marginalized. Throughout his career, Hughes observed and gave an original restitution of the historic evolution of the African-American dream and culture. With his musical aesthetics, his rhetorical innovation uncovered the various interpretations and assessment of the dreams of African Americans. His poetic technique also served important cultural and narrative functions. Through his poems, the reader is asked to be permanently active and is urged to decipher the different layers of meanings to be able to rebuild AfricanAmerican history and to listen to the different forms of Black music. As we shall see, the reader is caught in a process of "collective fiction" typical of "minority writing", as argued by Gilles Deleuze and Félix Guattari in Mille Plateaux (1980). Such process participates in the construction or the definition of a people being at the margin (or "minoritarians" in Deleuzian philosophy), and in the creative process of a poet writing from the margin:

A minority is not defined by the paucity of its numbers but by its capacity to become or, in its subjective geography, to draw for itself lines of fluctuation that open up a gap and separate it from the axiom constituting a redundant majority. (Parr 167)

5 It is important, here, to clarify Deleuze's "minority" concept since it is an English translation of the French mistranslation of Kafka's German "kleine Literatur". To understand the writings of Kafka, Deleuze and Guattari wondered how best to approach his work. They used the concept of "rhizome" to show the many entrances and interpretations of Kafka's work, which led to discuss the notion of "minor literature": "Kafka does not consider the problem of expression in an abstract or universal manner. He considers it in connection with minor literatures - the Jewish literature of Warsaw or Prague, for example". (Deleuze 1996:16) Therefore, the American-English word "minority" designates something very different from what Deleuze and Kafka meant when they wrote on "minorite" and "kleine". 
A minor literature is not the literature of a minor language but the literature a minority makes in a major language. But the primary characteristic of a minor literature involves all the ways in which the language is affected by a strong coefficient of deterritorialization. [...] The second characteristic of minor literatures is that everything in them is political. In "great" literatures, on the contrary, the question of the individual (familial, conjugal, etc.) tends to be connected to other, no less individual questions, and the social milieu serves as environment and background. (Deleuze 1996:16)

By considering the poetic description of the living conditions of African Americans, my intent is to offer an analysis of some of Montage's powerful poems through the poet's social lens. Thus, I will analyze Hughes's vision of the American Dream for his people and how he addressed some of the most pressing social issues of his time which reverberate in contemporary America. My essay also asserts that through this particular technique, Hughes's writing is constantly on the edge of musical and written forms; an hypotext which bonds his poems to minority writing and minor literature as defined by Deleuze and Guattari. The subterranean, encoded language Hughes displays in his poetry is typical of "minor literature". I will therefore argue that Hughes "encoded" the mainstream language to adapt it to his specific needs and to express differently what the mainstream language could not translate.

\section{Hughes's rhetoric of the dream}

The theme of the dream is a central motif of Langston Hughes's poetry that established the continuity between the depictions of simple African Americans and their "deferred" expectations. Hughes made poetic use of the African-American folklore to bond individuals into a community sharing the same oral tradition. He thus created an art form vested in the African-American experience:

Dreams have always figured prominently in the works of Langston Hughes. Hughes's work is devoted to outlining, celebrating, and agitating on behalf of the dreams of oppressed and marginalized peoples worldwide, with particular focus on the dreams of African Americans. (Tracy 223)

As early as 1932, in The Dream Keeper and Other Poems, Hughes wrote poems about his people and for his people on hopes, dreams, aspirations, life and love. In this first collection of poems, Hughes's message was universal and he wrote about the expectations of Black people. Hughes's poems in The Dream Keeper did not translate the bitterness and disillusions of the 1940s and 1950s as it appeared in Montage. The poems were optimistic and full of hope for the future of African Americans, as in "I, Too":

I, too, sing America.

I am the darker brother.

They send me to eat in the kitchen

When company comes [...].

Tomorrow,

I'll sit at the table

When company comes. [...]

Besides,

They'll see how beautiful I am

And be ashamed -

I, too, sing America.

Written at a time when Black beauty was celebrated by Black artists and writers to gain acceptance and respectability, this poem also revealed the Black self differently, in all 
its beauty and strength. Within a mostly hostile Black middle-class context, Hughes was one of the first poets of the 1920s (along with Jean Toomer) to show the beauty and grace of ordinary people - people who were paradigms of courage and bravery and who were not perceived as the embodiment of beauty. Hughes's first poems also offered the utopia of the American Dream to the imagination of Black people. Yet, the victory of the Second World War brought new promises and perspectives to a people who had already been forgotten after the First World War and who would be forgotten once again.

Twenty years later, the tone was different and "Dream Boogie" (388) or "Deferred" (413) came as the answer to the poems written in 1932. In Montage, Hughes wrote on the outcomes of years of segregation. Montage is, indeed, about the expected changes that did not come and the disillusions of Black people after the war. While the government of the United States ignored the rights promised to every citizen of the United States regardless of race or color, in Montage Hughes promoted the truth of the American Dream and the reality of Black Americans, including those who migrated to Harlem in New York. The following extract from "Not a Movie" (396) speaks for itself:

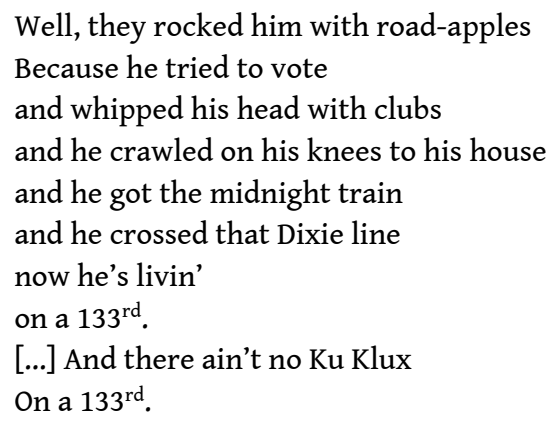

11 In the first half of the $20^{\text {th }}$ century, New York became an important center for the expanding Black middle-class. "Harlem, like many other urban Negro communities, underwent its most radical years of transformation and Negro settlement in the 1920's" (Osofsky 153). Hints at these changes, which accelerated as a consequence of World War I, are made clear in the poem. With the Great Migration, Harlem saw dramatic demographic changes at the beginning of the 1920s which transformed the area into a mostly Black and Latino part of the city.

If greatness is measured by size, the Great Migration was great indeed. Between America's entry into the European war and the stock market crash in 1929, black men and women left the South at an average rate of 500 per day, or more than 15,000 per month. The evacuation of the black belt was particularly striking. [...] By 1930, more than 1.3 million resided outside the South, nearly triple the number at the turn of the century (Berlin 154).

12 Harlem attracted black Southerners like a magnet and for those who settled there, Harlem embodied a dream come true: "Harlem was a magical, transforming place then, and this was especially true for the disenfranchised who came to New York in search of greater opportunity" (Bascom 4). Harlem was made a national symbol of the New Negro, and of the Jazz Age. In "Not a Movie," the poet makes us understand the reality and the violence of the South in the first half of the $20^{\text {th }}$ century: "Because he tried to vote / and whipped his head with clubs." The description of Southern violence helps the reader understand why and how Harlem became a magnet for black Southerners. Yet, as Gilbert Osofsky's study on Harlem between 1890 and 1930 reveals, New York had 
become a hostile place by the beginning of the $20^{\text {th }}$ century for Black people who did not escape racial antagonism despite settling there:

When the new century began the prevailing attitude toward the Negro in New York City had been one of hostility and increasing alienation. And as far as the majority of the population was concerned, there was no change in this dominant reaction of the city to the Negro people. The racial antagonism of the majority made necessary the creation of segregated communities like Harlem. (Osofsky 67)

The poem "Good Morning" (426), conceived like a testimony of Black migration to New York, also describes the consequences of this migration to the city (and other Northern cities). As suggested in the poem, the different migratory fluxes transformed Harlem, but the racial antagonism mentioned by Osofsky did not prevent Black people from continuing to migrate to Northern cities, particularly to New York:

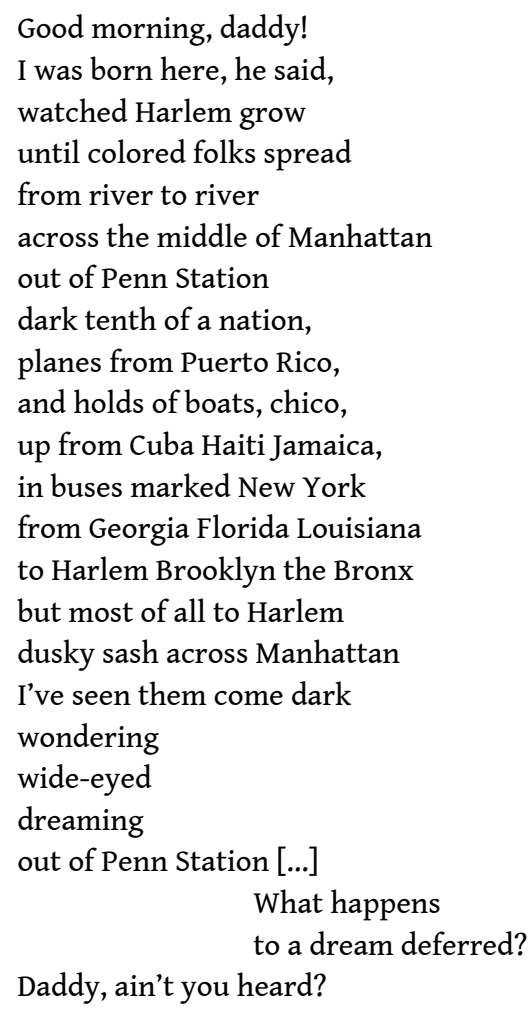

14 Here, the numerous names and nationalities suggest the diversity of the Black migrants and the power of attraction of the neighborhood. Nevertheless, the end of the poem suggests disappointment at unachieved expectations. The symbolism there suggests Black people were trapped in their own dreams and visions of Harlem, that they remained the prisoners of their dreams ("The gates open/ Yet there're bars/ at each gate"). By tackling the personal and social themes, Hughes made the dream and the "deferred dream" accessible to all, to connect to all African Americans and mostly to common people.

The poem "Deferred" (413), based on the topic of the deferred dream and placed just before "Good Morning" in the collection, already functioned as a warning and provided the irremediable conclusion. In "Deferred," Hughes confronts the dreams of different personas thanks to the use of italics which also suggest the changes and musicality of the different voices. The permanence of the oral voice is enhanced through a series of questions and comparisons, so that the poem can be read like a dialogue between two persons who answer each other. The italics translate what the character has (to have); 
the roman letters translate what the character is (to be). The dreams are about the desire to access culture, to work and also to consume, to have one's share of the American Dream. Here, the dreams are reduced to material possessions and consumption ("Maybe now I can have that white enamel stove/ I dreamed about when we first fell in love / [...] Maybe now I can buy that white enamel stove / [...] All I want is/ One more bottle of gin; / All I want is to see/ My furniture paid for./ [...] I want a television set."). This poem shows how dreams can be very common and ordinary and how the persona is impatient to get its part of the dream. By offering a voice to simple persons whose dreams are far from extraordinary, Hughes revealed his interest in common Black people.

\section{The musical aesthetics of the American Dream or Hughes's process of 'becoming'}

Early in his career, Hughes started to work on a fundamentally new kind of expression through poems that spoke of the joys and sorrows of ordinary Black folk, in the language of their typical speech. As Arnold Rampersad puts it in the introduction to The Collected Poems of Langston Hughes, "To respect Hughes's work, above all one must respect the African American people and their culture as well as the American people in general and their national culture." (Rampersad 5) African-American culture was indeed important to Hughes and part of his creativity process, and to the question "What is poetry?" he answered: "it is the human soul entire, squeezed like a lemon or a lime, drop by drop, into atomic words. A poet is a human being; each human being must live within his time, with and for his people, and within the boundaries of his country." (Rampersad 5)

Ordinary people were Hughes's permanent source of inspiration while Black music constituted a permanent source of experiments. Music is omnipresent in Montage. Blues is a recurrent form, and boogie-woogie is also exploited in several poems which are close to the same musical structure with syncopations, variations, and repetitions. To Hughes, the use of Black music was a fundamental way of establishing the continuity between African-American creativity and his own creativity which he inscribed in the African-American experience, the basis of racial pride. By intertwining the rhythm of Black music (blues, jazz or be-bop) to his writing, Hughes not only required readers to reconsider all assumptions on the literary use of folklore, he also created his own oral aesthetics to produce a new form of folk poetry. In so doing, Hughes exemplified the Harlem Renaissance's concern with creating an art form vested in the AfricanAmerican experience and showed his influence in the oral tradition. Hughes's specific style also expressed his rebellion against the Black middle-class ideals, his rejection of its orientation, and later in his career, his social criticism:

Hughes merged the African American oral and written traditions, exploiting conventions, techniques, and the goals of both to achieve a poetry that is intellectually stimulating, socio-politically responsible, and aesthetically pleasing, both as folk poetry and literature. (Tracy 2)

In the poems "Dream Boogie" (388), "Easy Boogie" (395), "Boogie 1 a.m." (411), "Lady's Boogie" (412), "Nightmare Boogie" (418) and "Dream Boogie: Variation" (425), which, as its title shows, is a variation on the poem which opens the collection, boogie-woogie is a key theme and also the principle of writing which unites the poems. By so doing, 
Hughes's rhetoric allowed him to disclose the various interpretations of the dreams of African Americans. It also inscribed him in a process of "becoming", or what Deleuze called "un devenir", namely "a becoming-poet" ("devenir-poète"). Hughes's technique puts music and writing in proximity so that the changes that are produced question the poet himself and his writing:

Becoming is the pure movement evident in changes between particular events. This is not to say that becoming represents a phase between two states, or a range of terms or states through which something might pass on its journey to another state. Rather than a product, final or interim, becoming is the very dynamism of change, situated between heterogeneous terms and tending towards no particular goal or end-state. [...] The human subject, for example, ought not to be conceived as a stable, rational individual, experiencing changes but remaining, principally, the same person. Rather, for Deleuze, one's self must be conceived as a constantly changing assemblage of forces, an epiphenomenon arising from chance confluences of languages, organisms, societies, expectations, laws and so on. (Parr 26-7)

These characteristics are typical of minor literature and show how the poet appropriated the language of the norm to write from the margin and for the people of the margin. Hughes's orality and musicality provide an aesthetics leading the reader to reconsider all assumptions which push him to create his own reading and interpretive grid, another characteristic of minor literature. The reader becomes a "nomad," to quote Lyotard's reflections on language, and is led to experience multiple intensities. The reader is also asked to assert his own understanding and interpretation. Hughes's expression evades the dominant linguistic model where reading becomes the expression of different and multiple interpretations. These multiple entries typify minor literature as defined by Deleuze:

[The] characteristics of minor literature [is] the deterritorialization of the language, the connection of the individual and the political, the collective arrangement of utterance. Which amounts to this: that "minor" no longer characterizes certain literatures, but describes the revolutionary conditions of any literature within what we call the great. (Deleuze 1996:18)

Such concepts may seem odd and ill-adapted when dealing with Hughes's poetry and technique. Yet, they apply to Hughes's writing and show how the poet built his own voice and expressed his personal orientation in a literary world dominated by the White Anglo-European tradition and by Black elitist ideals at odds with his own ideals. In an article on orality in the work of Zora Neale Hurston ("orality" being a term which we could replace by “musicality” to describe Hughes's writing), Trinna S. Frever notes:

Orality becomes an overarching aesthetic that shapes her [Zora Neale Husrton's] narrative along vocal and communal lines, as a sung melody rather than a linear typescript. In turn, this synthesized oral print text requires a reader to reconsider all assumptions brought to reading as an individual act, and a print form. (Frever 2)

21 In "Dream Boogie", two voices answer and echo each other and give their own version of the American Dream. They also offer a space of expression and of listening to common Black people:

Good morning, daddy!

Ain't you heard

The boogie-woogie rumble

of a dream deferred?

Listen closely:

You'll hear their feet

Beating out and beating out a- 


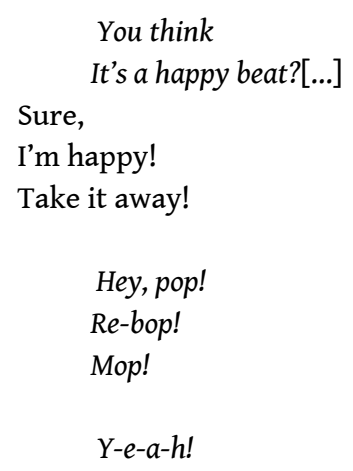

The oral communication is materialized with the italics which allow a change of tone. The main preoccupation of the persona is to be heard. The question: "ain't you heard?" is repeated twice, just like the verb to listen ("Listen closely / [...] Listen to it closely"). The semantic field of sound implies the persona wants the reader to be the witness of the evolution of the dreams which have become deferred ("Ain't you heard/ The boogie-woogie rumble/ of a dream deferred?"). Questions and exclamations appear alternately to demand full participation from the listening partner and, implicitly, from the reader. The reader must be an active one, fully engaged in the reading and interpretation of the poem, thus leading to the double-voice technique which Henry Louis Gates Jr. considers inherent to African-American texts and poems. By reinterpreting contemporary critical theory in 1988, Gates proposed to reconcile history and form through "the language of signifying". He examined myths and poetry found in African traditions to articulate the Black tradition's theory of its literature. He uncovered a system of interpretation that slaves of African ancestry brought with them to the New World. He thus grasped the meaning of the double-voice inherent to all African-American texts. With his theory of the "signifying monkey", Gates offered a new framework to examine major works of African-American literature (Gates 22).

In the poem, and as in boogie-woogie, the voice stops ("What did I say?") to be heard again more rapidly ("Sure, / I'm happy!/ Take it away!"). We can hear syncopations or scat with: "Hey, pop! / Re-bop!/ Mop! / Y-e-a-h!". The sadness and seriousness of the opening lines ("Ain't you heard / The boogie-woogie rumble / of a dream deferred?") are then replaced by happiness while the tempo is gathering speed: "Sure, I'm happy! / Take it away! / Hey, pop! / Re-bop!/ Mop! / Y-e-a-h!". In the poem "Nightmare Boogie" (418), the conflicting ideals of the American Dream start to appear:

I had a dream

And I could see

A million faces

Black as me!

A nightmare dream:

Quicker than light

All them faces

Turned dead white!

Boogie-woogie,

Rolling bass,

Whirling treble

of cat-gut lace. 

("Nightmare") and the first line: "I had a dream." The nightmare is opposed to the dream. The persona is aware of the need for political action and change for Black people which could materialize through a great gathering ("I had a dream / And I could see / A million faces/ Black as me!"), and yet this very idea turns into a nightmare ("A nightmare dream: / Quicker than light/ All them faces / Turned dead white!"). What Hughes is doing here differs from his earlier work, as his poetry works consciously to bolster Black personhood through obscure allusion. His writing followed, in fact, the evolution of his society and was in keeping with his time and denunciations. The simplicity of his style also shows his wish to make his ideas accessible to all. With this poem, the reader cannot help thinking of Martin Luther King's "I had a dream" speech, which echoes Hughes's own dream. King's "desire to connect with the heart of African Americans and his own cultural roots" (Miller 5) is indisputable, and Hughes's poems and vision of the dream were, undoubtedly, the basis of his thinking. With his famous 1963 speech, King gave new validity to the dreams of the oppressed which the poet had already envisioned a decade earlier.

his poem, adopting and fitting into the American Dream also leads to losing one's identity and culture ("All them faces/ Turned dead white!"); the end of the poem offers a form of optimism, however, since the musical imagery and the rhythm of boogiewoogie reappear: "Boogie-woogie, / Rolling bass, / Whirling treble, / Of cat-gut lace." Thus, to be receptive to boogie-woogie is a question of racial and social identity; to listen to music and to feel it is also a personal skill that Hughes's characters may or may not develop. In "Lady's Boogie" (412), for instance, the woman is unable to feel the music and to understand it:

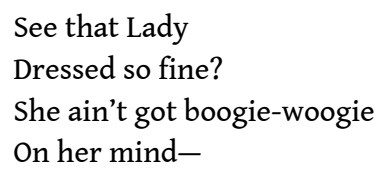

belongs to the Black bourgeoisie, this lady is not sensitive to this form of music and remains impervious to the dream deferred precisely because she is a lady. Hughes wants us to understand boogie-woogie not only as a musical style, but also a way of living which the lady does not share. This was also the way for the poet to express his rebellion against the African-American middle-class, showing how he wrote for marginalized people.

The musical rhetoric of boogie-woogie is central to Montage, but other forms of music such as jazz, blues and spirituals are also present in the poems and help portray Harlem daily life in the 1940s. These different forms of music connect Black people and allowed Hughes to foreground Black culture and identity. Spirituals, blues, and jazz are present in "Mystery" (416) and in "Testimonial" (417), while other poems recall jazz music and be-bop, such as "Flatted Fifths" (404), "Jam Session" (408), and "Be-Bop Boys" (409). Thus, all the poems of the collection function as polyphonic voices and echo each other; they also show music played a central role in Hughes's life, how it was a way of life for him. He successfully recaptured the American energy and inspiration during and after the war through these poems. He described the life of a community in transition. The victory of the Second World War was, indeed, full of promises for Americans, but for African Americans, the chasm between American social ideals and reality began to emphasize the need for action and changes. African Americans were always the losers 
of the American Dream. They needed to reinvent themselves to reclaim their part of the Dream. Different personas tell their own stories and propose a post-war inventory of the Black community living in Harlem. The poems also put the American Dream in perspective and offer a reflection on what prevented it from coming true for Black Americans. Beyond that, Hughes also wondered what future was to be expected and whether reclaiming the American Dream was actually a necessity for African Americans.

\section{The dialectics of the 'margin'} story of some of the Black people who decided to pass as White to have their share of the Dream to not remain in the social margins. Such act was a betrayal to one's culture and identity, but this was the price to pay to see the Dream come true. Hughes describes the cultural codes of the Black community ("Harlem has its / washed-andironed-and-cleaned-best out"). The isolation of those who crossed the color line ("the ones who've crossed the line/ to live downtown/ miss you") is translated on the page through the cuts of the words and lines ("Harlem and the bitter dream, / since their dream has / come true"). The conclusion of such isolation downtown is not given immediately, as if the poet wanted to maintain a form of suspense ("since their dream has come true"). The dream came true for those who crossed the color line, but they suffer as they miss their community and have lost all cultural values. Conversely, those who remain in Harlem, the symbol of the spatial margin, do not have their share of the dream but preserve their soul and cultural references.

The poems "Harlem [2]" (426) and "Good Morning" (426) show what the American Dream will become by putting it in perspective. "Harlem [2]" presents a series of questions which lead to an unexpected conclusion:

What happened to a dream deferred?

Does it dry up

like a raisin in the sun?

Or fester like a sore-

And then run?

Does it stink like rotten meat? [...]

Or does it explode?

The poems' originality lies in the multiple comparisons which all convey negative images and associate the American Dream with rot and decay ("like a sore", "like rotten meat"). The suddenness of the conclusion makes it even more unexpected ("Or does it explode?"). The interrogative voice is omnipresent and forces the reader to be active since he is asked different questions. The opening question "What happened to a dream deferred?" echoes the poem "Deferred" and the repetition of "a dream deferred", this time in the interrogative mode, comes as a bitter conclusion and assessment. Hughes translates, through an aggressive mode, the tensions between the reality of the Black experience and the unrealized dream. Tensions disappear as the collection of poems ends.

Montage ends with "Island [2]" (429), which echoes the opening poem with the repetition of "Good morning daddy", and comes as an optimistic counterpoint to "Harlem [2]". While "Harlem [2]" described the neighborhood as a place encapsulating 
all the frustrations provoked by the inaccessibility of the American Dream, "Island [2]" shows how Harlem became the place of the dream (my emphasis) for many African Americans. The poem is a celebration of Harlem, the ultimate place of the dream ("dream within a dream/ Our dream deferred"), a symbolic place for African Americans, encapsulating their dreams. Harlem is also the picture of the racial diversity of the Black diaspora: "Black and white, / Gold and brown- / Chocolatecustard/ Pie of a town". The two rivers ("Between two rivers, / North of the park, / Like dark rivers/ The streets are dark") symbolically unite the Black diaspora. The Mississippi river has now been replaced by the Hudson River and East River which offer renewal and opportunities to the diaspora, although disillusion is never far, as disappointment returns time and again like a lament ("Dream within a dream, Our dream deferred").

The theme of the "dream deferred" reappeared in Hughes's writing through his phenomenal Ask Your Mama: 12 Moods for Jazz. In this work, Hughes went further in his creative process and denunciation of the American Dream which was still unattainable for Black people. Through complex writing akin to modernism, which translates Hughes's evolution between the 1920s and 1960s, the poet settled his difference and anger at the American government, unable to offer a share of the American Dream to African Americans. In an ironic and sarcastic tone, Hughes provoked and demanded answers to concrete social issues. Loyal to Black music, Hughes followed its history and evolution and appropriated free-jazz to express his bitterness and his vision of the times he lived in (see Sylvanise 13). Free-jazz was another way to develop the relationship between his writing and music, as well as mirror the evolution of relations between African Americans and White Americans, and to highlight international relations between Africans and African Americans. Hughes's "free jazz style" was a way to express his political and stylistic evolution as he had become more radical over the years:

In 1960, near the dusk of his career, and the dawn of the civil rights movement, Langston Hughes began an epic poem in a hotel room in Newport, R.I. He had come for the Newport Jazz Festival to hear many of the most compelling musicians of the day: Oscar Peterson, Ray Charles, Muddy Waters, John Lee Hooker. A riot broke out at the festival that year when many fans - mostly young and white - were barred from entering the sold-out show and became violent. The festival's roaring rhythms and racial tensions made their way to the page, as Hughes penned what would be his longest poem, "Ask Your Mama: 12 Moods for Jazz". (Karpman 2009)

Through a disconcerting and improvised style, the reader is asked to become a listener and to understand the cyclic and repetitive aspect of history. In the 1950s, free-jazz musicians such as John Coltrane, Cecil Taylor or Ornette Coleman questioned traditional musical writing and explored new songs and a new tempo. Free-jazz marked a split with binary and ternary rhythms, and evolved with the Black Power movement. It became the expression of Black people's social discontent. To use this style was also a way to carry on questioning traditional writing and to break with literary habits. Hughes applied the free-jazz technique to his writing to lose the reader in a poetic maze. Like a free-jazz musician, he experimented new forms, a new style and pushed his reader to decode the layers of meanings and to appropriate his writing to find his way in this maze made of words and sounds. As Sylvanise remarks in Langston Hughes, poète jazz, poète blues (2009), the absence of punctuation stresses the effect of improvisation and is even more disconcerting for the reader (Sylvanise 176-7). Hughes, who had become more radical, wrote on the struggles Black people had to carry on to 
reach the American Dream. His call was a poetic and revolutionary one, somehow outside mainstream culture, to maintain an alternative to the poetry of the counterculture and the Beat generation. The following extract from "Cultural Exchange" (479) exemplifies these points:

\begin{tabular}{|l|l|}
\hline IN THE POT BEHIND THE & \\
PAPER DOORS WHAT'S COOKING? & \\
WHAT'S SMELLING LEONTYNE? & \\
LIEDER, LOVELY LIEDER & Delicate \\
AND A LEAF OF COLLARD GREEN. & lieder \\
LOVELY LIEDER LEONTYNE & on piano \\
& continues \\
IN THE SHADOW OF THE NEGROES & between verses \\
NKRUMAH & to merge \\
IN THE SHADOW OF THE NEGROES & softly \\
NASSER NASSER & into the \\
IN THE SHADOW OF THE NEGROES & melody of the \\
ZIK AZIKIWE & "Hesitation \\
CUBA CASTRO GUINEA TOURÉ & Blues" asking \\
FOR NEED OR PROPAGANDA & its haunting \\
KENYATTA & question, \\
AND THE TOM DOGS OF THE CABIN & "How long \\
THE COCOA AND THE CANE BRAKE & must I \\
& wait? \\
\hline
\end{tabular}

The margin is a signal which asks the same recurrent question. "How long must I wait?" echoes the question Hughes asked ten years earlier with "What happens to a dream deferred?" The dream, and longing for the dream, are leitmotivs which suggest Black Americans did not have their share of the dream at the time Hughes wrote his poems. The poet thus became more radical and invoked his community to mobilize itself and fight against American imperialism. By mentioning "Castro, Nasser, Touré," Hughes suggested to all Black people around the world to unite and fight oppression, be it racial and/or social. The margin also points at the musicality of Hughes's poetry which was also built like musical pieces:

\begin{abstract}
Ask Your Mama was never meant to be simply read silently to oneself. Alongside the words of the poem, Hughes sketched out detailed instructions for musical accompaniment. He planned to stage an elaborate performance of his piece with the help of jazz musician and composer Charles Mingus, but died before seeing it to fruition. (Karpman 2009)
\end{abstract}

Later in the poem, the motive of the dream reappears and ironically points at the impossibility of the dream for African Americans:

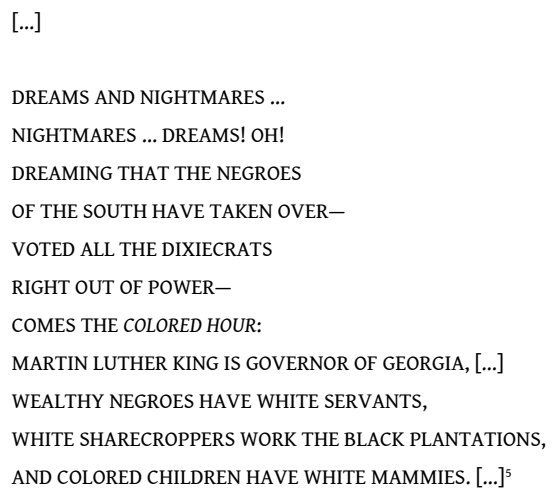

Figure impishly into "Dixie" ending in high shrill flute call TACIT 

created disillusions. The poems are the depiction of mixed results and outcomes, after years of segregation and injustice for African Americans. As Arnold Rampersad puts it in the introduction to The Collected Poems of Langston Hughes: "[Hughes] is among the most eloquent American poets to have sung about the wounds caused by injustice" (Rampersad 3). The poems in both Montage and Ask Your Mama, denounce the social and economic policies of the American government which systematically forgot Black people excluded from the American Dream. With its polyphonic structure, Montage and Ask Your Mama are also deeply original. The poems, which are built on the same rhythm as boogie-woogie, or free-jazz for the second collection, must be understood in their continuity and show Hughes's search for musical poetry and poetic innovation which were his life's leitmotiv. Hughes's creative and poetic experiments carried on through Ask Your Mama and showed the poet's strong desire to write on his society and on the place of his community in society. Poetic, provoking and revolutionary, Hughes fought his whole life to provide a work devoted to the humble. His simplicity of style and his original poetic creation participated in the construction of a new African-American literature marked by modernism and the merging of cultures.

These ideas about nationality, ethnicity, authenticity, and cultural integrity are characteristically modern phenomena that have profound implications for cultural criticism and cultural history. They crystallized with the revolutionary transformations of the West at the end of the eighteenth and the beginning of the nineteenth centuries and involved novel typologies and modes of identification. (Gilroy 2)

The act of representing the American Dream through the lens of the Black American poet is linked with "the circulation of meaning", to quote Homi Bhabha (287). For Hughes, the subversion of language constituted an act of resistance for the survival of Black culture and memory. This form of writing also testifies to the modernist attempt "to elaborate a historical and literary project." (Bhabha 248) To paraphrase Gilroy, Hughes's poetry is inscribed in the political culture of Blacks and symbolizes "the struggle to have blacks perceived as agents, as people with cognitive capacities and even with an intellectual history." (Gilroy 6) Sure enough, in a context of increasing racial tensions, Hughes's pending question: "What happens to a dream deferred?" takes even more significance and reverberates all along the reading and the interpretation of 
the poems. As Kwame Anthony Appiah stated in a recent article: "The dream of a world beyond race, unfortunately, is likely to be long deferred." (Appiah 21) ${ }^{6}$

\section{BIBLIOGRAPHY}

Appiah, Kwame Anthony. "Race in the Modern World. The Problem of the Color Line". Foreign Affairs, Vol. 94, 2 (2015): 1-8. https://www.foreignaffairs.com/articles/united-states/2015-03-01/ race-modern-world

Archer-Straw, Petrine. Negrophilia. New York: Thames \& Hudson, 2000.

Bhabha, Homi. The Location of Culture. London: Routledge Classics, 2004.

Bascom, Lionel C. (ed.). A Renaissance in Harlem. New York: Avon Books, 1999.

Berlin, Ira. The Making of African America. The Four Great Migrations. New York: Penguin Books, 2010.

Deleuze, Gilles. Kafka. Pour une littérature mineure. Paris: Editions de Minuit, 1975. Trans. by Robert Brinkley as What Is a Minor Literature? in Mississippi Review, Vol. 11 (3), Essays Literary Criticism (Winter/Spring, 1983), U. of Southern Mississippi, 1996: 13-33. https://www.jstor.org/stable/ 20133921

Deleuze, Gilles. Mille plateaux. Paris: Minuit, 1980.

Frever, Trinna S., "'Mah Story Ends,' or Does It?: Orality in Zora Neale Hurston's 'The Eatonville Anthology'." Journal of the Short Story in English, 47 (Autumn 2006). https://

journals.openedition.org/jsse/788

Gates Jr., Henry Louis. The Signifying Monkey. A Theory of African American Literary Criticism. New York, Oxford: Oxford UP, 1988.

Gilroy, Paul. The Black Atlantic, Modernity and double consciousness. New York: Verso, 1995.

Hughes, Langston. The Collected Poems of Langston Hughes, see Rampersad (1995).

Karpman, Laura. "Jessye Norman, the Roots Team Up for Langston Hughes' 'Ask Your Mama'." PBS Newshour, August 27, 2009. http://www.pbs.org/newshour/art/jessye-norman-the-rootsteam-up-for-langston-hughes-ask-your-mama/

Leroi, Jones. Blues People. Negro Music in White America. New York: Harper Perennial, 2002 (1963).

Miller, W. Jason. Origins of the Dream. Hughes's Poetry and King's Rhetoric. Gainesville: UP of Florida, 2015.

Osofsky, Gilbert. Harlem: The Making of a Ghetto. New York: Harper Torchbooks, 1971 ( $2^{\text {nd }}$ edn.).

Parr, Adrian, ed. The Deleuze Dictionary. Edinburgh: Edinburgh UP, 2005 [2010] (revised edn.).

Rampersad, Arnold (ed.). The Collected Poems of Langston Hughes. New York: Vintage Classics, 1995.

Sylvanise, Frédéric. Langston Hughes, poète jazz, poète blues. Lyon: ENS Editions, 2009.

Tracy, Steven. Langston Hughes and the Blues. Champaign: U. of Illinois P., 2001. 


\section{NOTES}

1. In the remainder of the paper, I will refer to Hughes's poems in Montage of a Dream Deferred as Montage. I will also use the version by Arnold Rampersad (1995) for all the poems quoted.

2. The Harlem Renaissance was a period of interest in African-American art and culture; racial pride and identity were defined by black intellectuals living in Harlem. This artistic movement claimed the full participation of African Americans in American society.

3. Leroi Jones considers blues as old as the presence of Black people in the United States (see Jones 17).

4. Hughes refers in the poem to Leontyne Price (1927) who interpreted Aïda and became internationally famous with her interpretation. He also uses 'lieder' in the sense favored by jazz musicians. Initially, a 'lieder' was a German poem sung with one voice and a piano accompaniment. To see the poem on the printed page: https:// nyumodernworkinggroup.files.wordpress.com/2011/04/hughes-langston-ask-your-mama.pdf

(p. 479-480).

5. See note 4.

6. According to Appiah, a New York University professor, differences and racial hostility are still a major problem and racial identities continue to define groups' social identity; America has not moved into a post-racial world and it is not moving beyond ethno-racial identities.

\section{ABSTRACTS}

In his collection of poems entitled Montage of a Dream Deferred (1951) Langston Hughes observed and gave an original restitution of the historic evolution of African-American culture, a theme he reverted to again in 1961 with Ask Your Mama: 12 Moods for Jazz. Both collections were, indeed, largely shaped by the impact of the transformation of black music as well as the hopes and dreams of African Americans. The theme of the American Dream and the possibilities for the black man to reach and accomplish this dream were recurrent in Hughes's poetry, while the tension between the realities of the black experience and the unrealized dream provided the dynamic of his writing. By considering the poetic description of the living conditions of African Americans, my intent is to offer an analysis of the poet's social lens to understand his vision of the American Dream for his people and how he addressed some of the most pressing social issues of his time. By analyzing Hughes's poetic technique, I will also show how the poet rebuilt AfricanAmerican history and led the reader to a process of "collective fiction", typical of "minority writing", as defined by Gilles Deleuze and Félix Guattari in Mille Plateaux (1980). Through his specific technique, we will see Hughes's writing is constantly on the edge of musical and written forms; an hypotext which bonds his poems to minority writing and minor literature.

Dans les recueils de poèmes Montage of a Dream Deferred (1951) et Ask your Mama: 12 Moods for Jazz (1960), Langston Hughes livre une restitution particulièrement originale de la communauté noire et de son histoire entre les années 1940 et 1960. Les deux recueils suivent effectivement l'évolution de la musique noire en même temps que les rêves et les attentes de la communauté noire américaine. Le thème du rêve américain et la possibilité d'avoir sa part du rêve pour la communauté noire est récurrent dans l'écriture de Hughes. Les tensions entre les attentes et la réalité fournissent aussi une dynamique d'écriture propre au poète. A travers notre analyse, nous 
montrerons en quoi la description "socio-poétique» de Hughes traduit sa vision du rêve américain et comment il aborde la question sociale la plus brûlante de son temps à travers une écriture poétique qui se veut à la fois stimulante et accessible à tous. En analysant le style et la technique de Hughes, nous verrons aussi comment le poète a réinterprété l'histoire et réinvesti la langue. En substituant à la langue des expressions langagières et des modulations écrites depuis la marge, une caractéristique propre à la « littérature mineure » définie par Gilles Deleuze et Félix Guattari dans Mille Plateaux (1980), Hughes parvient ainsi à mettre le familier à distance, à s'affranchir de la norme, et à imposer une forme de représentation du mineur et de la marge au sens deleuzien.

\section{INDEX}

Mots-clés: Hughes Langston, rêve américain, socio-poétique, Deleuze Gilles, marge, littérature mineure

Keywords: Hughes Langston, American dream, socio-poetics, Deleuze Gilles, margin, minor literature

\section{AUTHOR}

\section{CHRISTINE DUALÉ}

Associate professor HDR at Université Toulouse Capitole. CAS member (EA 801), Université Toulouse 2 Jean Jaurès and CELIS - Centres de Recherches sur les Littératures et la Sociopoétique (EA1002), Université Clermont Auvergne. Author of Les Noirs et la réussite universitaire aux ÉtatsUnis, Paris: L'Harmattan, (2007); Harlem Blues. Langston Hughes et la poétique de la renaissance afroaméricaine. Paris: L'Harmattan (2014); Langston Hughes et la Renaissance de Harlem: émergence d'une voix noire américaine. Paris: L'Harmattan (2017). Fields of interest: Langston Hughes, Harlem Renaissance, African American culture, Deleuzian concepts: "margin, minor literature, rhizome". Contact: christine.duale [at] ut-capitole.fr 